\title{
Strategy of Sample Preparation for Arsenic Determination in Mineral Fertilizers
}

\author{
Raquel C. Machado, ${ }^{a, b}$ Edenir R. Pereira-Filho ${ }^{a}$ and Ana Rita A. Nogueira*,a,b \\ ${ }^{a}$ Grupo de Análise Instrumental Aplicada, Departmento de Química, Universidade Federal de São \\ Carlos, 13565-905 São Carlos-SP, Brazil \\ ${ }^{b}$ Embrapa Pecuária Sudeste, 13560-970 São Carlos-SP, Brazil
}

\begin{abstract}
A method for determination of arsenic in mineral fertilizers by continuous flow hydride generation atomic absorption spectrometry (CF-HG-AAS) was developed by using diluted acid and digester block with perfluoroalkoxy (PFA) tubes to sample preparation. An additional sample preparation procedure using microwave-assisted digestion was evaluated and compared with the proposed procedure. A full factorial design was applied to investigate the effect of the variables and the best conditions found were $7 \mathrm{~mol} \mathrm{~L}^{-1} \mathrm{HNO}_{3}+30 \%(\mathrm{~m} / \mathrm{m}) \mathrm{H}_{2} \mathrm{O}_{2}$ as reagents, $4 \mathrm{~h}$ of digestion and concentration of reagents diluted 1:1. The effect of concomitants on the analytical signal of arsenic was investigated and no one significant interference was observed, with recoveries ranged from 97 to $103 \%$. The accuracy of proposed method was evaluated by certified reference material (NIST SRM 695) and recovery of $95 \%$ was obtained. The arsenic concentration $\left(8.9 \pm 0.2 \mathrm{mg} \mathrm{kg}^{-1}\right)$ found in the fertilizer is below of maximum concentration established by Brazilian legislation.
\end{abstract}

Keywords: sample preparation, mineral fertilizers, arsenic, factorial design, CF-HG-AAS

\section{Introduction}

Mineral fertilizers are added to provide the soil the three basic plant nutrients: nitrogen, phosphorus and potassium. Some fertilizers also contain micronutrients, such as zinc and iron, and other nutrients that are necessary for plant growth. Beyond these nutrients, mineral fertilizers may also be a source of toxic trace elements, as arsenic, derived from rocks, organic matter and certain industrial wastes. ${ }^{1,2}$

Arsenic occurs naturally in the soil, but the application of fertilizers in cropland soil has increased its amount, causing contamination that contributed for the enhance of arsenic absorption and accumulation by plants. ${ }^{3,4}$ The arsenic exposure can cause serious health effects, such as diabetes, skin lesions, neurological effects, cardiovascular disease and the occurrence of different forms of cancer.,

Different procedures of sample preparation have been reported in the literature for determination of trace metals in fertilizers samples, such as the use of methods 3051 and 3050-B, defined by the United States (US) Environmental Protection Agency (EPA); ${ }^{7,8}$ acid mixtures, as $\mathrm{HNO}_{3}+\mathrm{HF}+\mathrm{HCl},{ }^{8} \mathrm{HNO}_{3}+\mathrm{HF},{ }^{9}$ and $\mathrm{HNO}_{3}+\mathrm{HCl} ;{ }^{5}$ slurry sampling $;{ }^{8,10,11}$ and ultrasound-assisted extraction. ${ }^{4}$ However,

*e-mail: ana.nogueira@embrapa.br most of these works uses concentrated acids during sample preparation step, generating larger amount of waste, needed for dilutions to fit the instrumental detection methods and do not follow the principles of green analytical chemistry. ${ }^{12,13} \mathrm{In}$ this context, the use of diluted acid for sample decomposition is an alternative to procedures existing and a strategy to minimize the reagent consumption, residues generation and blank analytical values. ${ }^{13}$

There are few reports on the use of diluted acid in sample decomposition of fertilizers. Macedo et al. ${ }^{10}$ prepared slurry from diluted acids for determination of total arsenic and arsenic(III) in phosphate fertilizer. Souza et al. ${ }^{14}$ proposed the use of diluted acids for macronutrients, micronutrients and trace elements determination in mineral fertilizers. The procedures developed by authors were adequate for the determination of the analytes with appropriates precision and accuracy, indicating the feasibility of using diluted acid to fertilizers digestion.

Diverse analytical techniques can be used for arsenic determination, among which the hydride generation atomic absorption spectrometry (HG-AAS) stands out by adequate sensitivity and selectivity due to the separation of the analyte from the matrix, minimizing interferences. ${ }^{15}$ It is a simple and of low operational cost technique. Otherwise, it requires attention to the effect of arsenic oxidation state 
during the hydride formation, since $\operatorname{arsenic}(\mathrm{V})$ has lower reduction kinetics than arsenic(III), causing depreciation in the analytical signal. The reagents used in sample preparation step can also interfere with the formation and release of arsenic hydride. ${ }^{16-18}$

In this work, a method for arsenic determination in mineral fertilizers by using continuous flow HG-AAS (CF-HG-AAS) was developed, combining sample decomposition procedure with diluted acid and digester block with PFA vessels.

\section{Experimental}

\section{Reagents, solutions and samples}

All the reagents used were of analytical grade and the solutions were prepared using deionized water $(18 \mathrm{M} \Omega \mathrm{cm}$ resistivity), obtained from a Milli- $\mathrm{Q}^{\circledR}$ Water System (Millipore, Bellerica, MA, USA). All glassware and polypropylene flasks were washed with soap, soaked $12 \mathrm{~h}$ in $10 \%(\mathrm{v} / \mathrm{v}) \mathrm{HNO}_{3}$, rinsed with deionized water and dried in a laminar flow hood. Arsenic standard solutions from 1.0 to $40.0 \mu \mathrm{g} \mathrm{L} \mathrm{L}^{-1}$ were prepared after successive dilutions of $1000 \mathrm{mg} \mathrm{L}^{-1}$ stock solution (Qhemis, São Paulo, SP, Brazil). Solutions of $12 \%(\mathrm{~m} / \mathrm{v}) \mathrm{KI}$ (Mallinckrodt, Mexico City, Mexico) and $0.9 \%(\mathrm{~m} / \mathrm{v}) \mathrm{NaBH}_{4}$ (Sigma-Aldrich, St. Louis, MO, USA), daily prepared in $0.5 \%(\mathrm{~m} / \mathrm{v})$ of $\mathrm{NaOH}$ (Qhemis, São Paulo, SP, Brazil), were used as prereducing and reducing arsenic solutions, respectively. Nitric acid and hydrochloric acids (J. T. Baker, Philipsburg, NJ, USA) were previously purified employing a a sub-boiling system a sub-boiling system model MA075 (Marconi, Piracicaba, SP, Brazil). Aqua regia daily prepared and 30\% $(\mathrm{m} / \mathrm{m}) \mathrm{H}_{2} \mathrm{O}_{2}$ (Qhemis, São Paulo, SP, Brazil) were also employed. The concomitants effect were evaluated with dilutions of $1000 \mathrm{mg} \mathrm{L}^{-1} \mathrm{Ca}, \mathrm{B}, \mathrm{Co}, \mathrm{Cr}, \mathrm{Cu}, \mathrm{Fe}, \mathrm{Mg}, \mathrm{Mn}, \mathrm{Ni}$, $\mathrm{Pb}$ and $\mathrm{Zn}$ stock solutions (Qhemis, São Paulo, SP, Brazil). Trace elements in multi-nutrient fertilizer, SRM 695, from the National Institute of Standard and Technology (NIST, Gaithersburg, MD, USA) was the certified reference material (CRM) used for accuracy evaluation. A sample of mineral fertilizer was provided by National Laboratory for Agriculture, LANAGRO (Goiania, GO, Brazil).

\section{Instrumentation}

The analytical signals were obtained by a fast sequential flame atomic absorption spectrometer model AA240FS (Varian, Inc., Palo Alto, CA, USA) fitted with deuterium background correction. As primary radiation source, a hollow cathode lamp for arsenic $(193.7 \mathrm{~nm})$ was used. The flame composition was air/acetylene $\left(13.5 / 2.0 \mathrm{~L} \mathrm{~min}^{-1}\right)$ and a T-shaped quartz cell atomizer (accessories of the VGA 77 system; Agilent Technologies, Santa Clara, CA, USA). All measurements were based on signal height. The instrumentals operating parameters, such as hollow cathode lamp current and spectral resolution, were the same as recommended by the manufacturer. The system of CF-HG-AAS employed in this work was previously optimized. ${ }^{19}$ It was composed by 8 channels peristaltic pump (MCP model; Ismatec, Wertheim, Germany), Tygon ${ }^{\circledast}$ propulsion tubes (Saint-Gobain, Courbevoie, France) with different diameters, a gas-liquid separator. A mass flow controller (ASA Srl, Sesto San Giovanni, MI, Italy) was utilized to control the carrier gas argon flow rate (White Martins, São Paulo, SP, Brazil).

To compare the obtained results, two instrumental methods were evaluated: an inductively coupled plasma optical emission spectrometer (ICP OES) iCAP 6000 (Thermo Fisher Scientific, Waltham, MA, USA), operating in radial view mode; and instrumental neutron activation analysis (INAA). The ICP OES instrumental operating conditions were $1150 \mathrm{~W}$ of radio frequency applied power; concentric type nebulizer with a cyclonic spray chamber and plasma gas, nebulizer and auxiliary flow rates were $0.70,12$, and $0.5 \mathrm{~L} \mathrm{~min}^{-1}$, respectively. The used emission line wavelength was $189 \mathrm{~nm}$.

For the INAA procedure, $122 \mathrm{mg}$ of samples were individually wrapped in aluminum foils and sealed into high purity polyethylene vials. These containers were irradiated in the Nuclear Energy Research Institute, National Nuclear Energy Commission (IPEN/CNEN), by using a thermal flux of $10^{13} \mathrm{n} \mathrm{cm}^{-2} \mathrm{~s}^{-1}$ for $8 \mathrm{~h}$ in the nuclear research reactor IEA$\mathrm{R} 1 \mathrm{~m}$. For the gamma-ray counting, a germanium detector with $50 \%$ relative efficiency was used.

\section{Sample preparation}

Two sample preparation procedures were evaluated, by using digester block (Tecnal, Piracicaba, SP, Brazil) with PFA vessels (Savillex, Eden Prairie, MN, USA) and microwaveassisted digestion equipped with a rotor with ten vessels (Ethos 1, Milestone, Sorisole, BG, Italy). In both procedures, a full factorial design was applied to a digestion of $200 \mathrm{mg}$ of SRM 695 and the following variables were investigated: (i) reagents $\left(7 \mathrm{~mol} \mathrm{~L} \mathrm{~L}^{-1} \mathrm{HNO}_{3}+30 \% \mathrm{~m} / \mathrm{m} \mathrm{H}_{2} \mathrm{O}_{2}\right.$, or aqua regia); (ii) digestion time ( 3 or $4 \mathrm{~h}$ for digestion block); and (iii) concentration of the reagents (diluted 1:1 or not diluted). The microwave oven program was performed in two steps: (i) $20 \mathrm{~min}, 200^{\circ} \mathrm{C}, 1100 \mathrm{~W}$ (ramp); and (ii) $20 \mathrm{~min}, 200^{\circ} \mathrm{C}$, $1100 \mathrm{~W}$ (hold). Recoveries of arsenic, normalized between 0 and 1 using the function of desirability, ${ }^{20}$ was utilized as a response. 
A commercial fertilizer was digested employing $7 \mathrm{~mol} \mathrm{~L}^{-1} \mathrm{HNO}_{3}+30 \%(\mathrm{~m} / \mathrm{m}) \mathrm{H}_{2} \mathrm{O}_{2}$ and using diluted reagent in the two evaluated digestion procedures, digester block with PFA vessels and microwave-assisted digestion.

\section{Pre-reduction step and arsenic hydride generation}

After digestion, the pre-reduction step was carried out by the addition of $4.17 \mathrm{~mL}$ of $6.0 \mathrm{~mol} \mathrm{~L}^{-1} \mathrm{HCl}+2.08 \mathrm{~mL}$ of $12 \%(\mathrm{~m} / \mathrm{v}) \mathrm{KI}$ to the samples and standard curve. All solutions were then heated for $10 \mathrm{~min}$ at $80{ }^{\circ} \mathrm{C}$ in a water bath model Aqua Wave 9376 (Barnstead Lab-Line, Dubuque, IA, USA) and the volume was adjusted up to $25 \mathrm{~mL}$ with deionized water. The final concentrations were $1.0 \mathrm{~mol} \mathrm{~L}^{-1} \mathrm{HCl}$ and $1.0 \% \mathrm{KI}(\mathrm{m} / \mathrm{v})$.

To arsenic hydride generation, the flow system was performed by using the pre-reduced sample solution (6.8 $\left.\mathrm{mL} \mathrm{min}^{-1}\right), 0.9 \mathrm{~mol} \mathrm{~L}^{-1} \mathrm{NaBH}_{4}\left(1.2 \mathrm{~mL} \mathrm{~min}^{-1}\right.$, the reduction agent) and $8.0 \mathrm{~mol} \mathrm{~L}^{-1} \mathrm{HCl}\left(1.2 \mathrm{~mL} \mathrm{~min}{ }^{-1}\right){ }^{20}$ The optimum conditions for the CF-HG-AAS system were previously reported by Guerra et al. ${ }^{21}$ such as the length of the reaction coil, the delay and the measurement times.

\section{Results and Discussion}

\section{Physical and chemical optimization parameters}

The full factorial design was used for evaluating the variables that would contribute to the best recoveries of arsenic obtained by CF-HG-AAS. The individual desirability $\left(\mathrm{d}_{\mathrm{i}}\right)$ was calculated employing the function of desirability to maximized responses and considering the arsenic recoveries. These values were normalized between 0 and 1.
For the digester block procedure, a $2^{3}$ full factorial design was carried out, totaling eight experiments. The results are present in Table 1.

The variable c (reagent concentration) and the interaction between variables $\mathrm{a}$ and $\mathrm{b}$ (reagent and digestion time, respectively) presented the main effects, indicating that all the variables are significant, i.e., influence the analytical response. To choose the best conditions, we used the value of the closest of the desired $\left(\mathrm{d}_{\mathrm{i}}=1\right)$. Experiment two has a value of the $d_{i}$ closest to $1\left(d_{i}=0.975\right)$; however, in this experiment aqua regia was used as digester reagent. Otherwise, according to Batista et al. ${ }^{20}$ and Takase et.al. ${ }^{15}$ concentrations of $\mathrm{HNO}_{3}$ higher that $10 \%$ (v/v) can decrease the analytical signal of arsenic. Therefore, the experiment three, that employed diluted acid, with the second value of $\mathrm{d}_{\mathrm{i}}$ closest to the desired $\left(\mathrm{d}_{\mathrm{i}}=0.750\right)$, was selected for digestion block with PFA vessels.

A $2^{2}$ full factorial design, in a total of four experiments, was used to choose the microwave-assisted digestion conditions. The results are presented in Table 2.

The variable a (reagent) was the only variable that presents influence in the arsenic recovery. The variable $b$ was not considered important for the analytical response in the evaluated conditions and was fixed at the lowest level (with 1:1 dilution of reagents). Moreover, the individual desirability value was also considered, which in the experiment one is closest to the desired value. Therefore, this experiment was selected for microwave-assisted digestions.

In Table 3, the optimized conditions for the two digestion procedures are presented. It could be observed the agreement between the experimental conditions for both procedures. Comparing the certified and determined arsenic values obtained by the two proposed digestion procedures, statistically similar results were obtained at 95\% confidence level.

Table 1. Recoveries of arsenic for certified reference material (NIST SRM 695) and individual desirability $\left(\mathrm{d}_{\mathrm{i}}\right)$ values obtained from a full factorial design $2^{3}$, considering reagents, digestion time and reagent concentration in the digester block with perfluoroalkoxy (PFA) vessels. Values of experimental conditions normalized

\begin{tabular}{lccccc}
\hline Experiment & Reagent & Digestion time / h & Reagent concentration & Recovery / \% & $\mathrm{d}_{\mathrm{i}}$ \\
\hline 1 & $\mathrm{HNO}_{3}+\mathrm{H}_{2} \mathrm{O}_{2}(-1)$ & $3(-1)$ & diluted 1:1 (-1) & 120.0 & 0.025 \\
2 & aqua regia (1) & $3(-1)$ & diluted 1:1 (-1) & 99.5 & 0.975 \\
3 & $\mathrm{HNO}_{3}+\mathrm{H}_{2} \mathrm{O}_{2}(-1)$ & $4(1)$ & diluted 1:1 (-1) & 95.0 & 0.750 \\
4 & aqua regia (1) & $4(1)$ & diluted 1:1 (-1) & 117.0 & 0.150 \\
5 & $\mathrm{HNO}_{3}+\mathrm{H}_{2} \mathrm{O}_{2}(-1)$ & $3(-1)$ & undiluted (1) & 125.0 & 0 \\
6 & aqua regia (1) & $3(-1)$ & undiluted (1) & 127.0 & 0 \\
7 & $\mathrm{HNO}_{3}+\mathrm{H}_{2} \mathrm{O}_{2}(-1)$ & $4(1)$ & undiluted (1) & 128.0 & 0 \\
8 & aqua regia (1) & $4(1)$ & undiluted (1) & 127.0 & 0 \\
\hline
\end{tabular}

Number in brackets: coded the variables in planning $2^{3}$. 
Table 2. Recoveries of arsenic for certified reference material (NIST SRM 695) and individual desirability $\left(\mathrm{d}_{\mathrm{i}}\right)$ values obtained from a full factorial design $2^{2}$ considering reagents and reagent concentration in microwave-assisted digestion. Values of experimental conditions normalized

\begin{tabular}{lcccc}
\hline Experiment & Reagent & Reagent concentration & Recovery / \% & $\mathrm{d}_{\mathrm{i}}$ \\
\hline 1 & $\mathrm{HNO}_{3}+\mathrm{H}_{2} \mathrm{O}_{2}(-1)$ & diluted 1:1(-1) & 103 & 0.875 \\
2 & aqua regia (1) & diluted 1:1 (-1) & 83 & 0.150 \\
3 & $\mathrm{HNO}_{3}+\mathrm{H}_{2} \mathrm{O}_{2}(-1)$ & undiluted (1) & 108 & 0.625 \\
4 & aqua regia (1) & undiluted (1) & 133 & 0 \\
\hline
\end{tabular}

Number in brackets: coded the variables in planning $2^{2}$.

Table 3. Optimized conditions for certified reference material (NIST SRM 695) arsenic recoveries by using the evaluated sample preparation procedures (digester block with perfluoroalkoxy vessels and microwave-assisted digestion) and determination by continuous flow hydride generation atomic absorption spectrometry (CF-HG-AAS)

\begin{tabular}{lcc}
\hline Parameter & Digester block & Microwave-assisted digestion \\
\hline Reagent & $7 \mathrm{~mol} \mathrm{~L}^{-1} \mathrm{HNO}_{3}+30 \%(\mathrm{~m} / \mathrm{m}) \mathrm{H}_{2} \mathrm{O}_{2}$ & $7 \mathrm{~mol} \mathrm{~L}^{-1} \mathrm{HNO}_{3}+30 \%\left(\mathrm{~m} / \mathrm{m}^{2} \mathrm{H}_{2} \mathrm{O}_{2}\right.$ \\
time & $4 \mathrm{~h}$ & fixed (50 min/digestion) \\
Reagent concentration & diluted $1: 1$ & diluted $1: 1$ \\
Certified value / $\left(\mathrm{mg} \mathrm{kg}^{-1}\right)$ & & $200 \pm 5$ \\
Determined value / $\left(\mathrm{mg} \mathrm{kg}^{-1}\right)$ & $186 \pm 9$ & $205 \pm 18$ \\
Recovery / $\%$ & 95 & 103 \\
\hline
\end{tabular}

Mean $(n=5) \pm S D$.

The sample digestion procedures presented similar

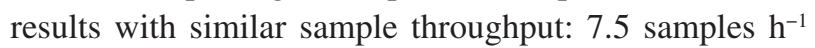
for digester block and 8.0 samples $\mathrm{h}^{-1}$ for microwaveassisted digestion. The use of the digester block with PFA vessels provides as satisfactory results as the obtained by microwave-assisted digestion for arsenic determination in mineral fertilizers. Furthermore, this procedure can be easily implemented in routine laboratories.

\section{Concomitants}

Several elements present in mineral fertilizers, when in high amounts, can be easily reduced by $\mathrm{NaBH}_{4},{ }^{15}$ affecting the release of arsenic hydride. In this study, we used different arsenic:concomitant ratios remained $20 \mu \mathrm{g} \mathrm{L} \mathrm{L}^{-1} \mathrm{As}$. The selected concomitants (potential interfering) were $\mathrm{Cu}$ (1:10) and $\mathrm{Ni}(1: 1)$, and others elements commonly present in the composition of mineral fertilizers, such as: $\mathrm{Fe}, \mathrm{Mg}$ and $\mathrm{Ca}$ (1:500); $\mathrm{Mn}$ and $\mathrm{Zn}$ (1:50); B (1:40); and $\mathrm{Cr}$ and $\mathrm{Pb}$ (1:5). The recoveries, between 97 and 103\%, suggest that the concomitants do not interfere with the arsenic analytical signal in the CF-HG-AAS determination. The results obtained with real samples, presented in Table 4, suggested more complexes samples.

\section{Comparison of arsenic determination by CF-HG-AAS, ICP OES and INAA}

Although the experimental conditions have been optimized with the CRM, mineral fertilizers normally present different composition. Therefore, to know the applicability of the CF-HG-AAS proposed procedure, the amount of arsenic obtained in sample of commercial fertilizer was compared with results obtained by ICP OES and INAA.

A commercial mineral fertilizer sample was digested employing the two optimized digestion procedures (see conditions in Table 3), and the amount of arsenic determined by CF-HG-AAS and ICP OES are shown in Table 4. A paired $t$-test presented no statistical difference between the results obtained by both the sample preparation procedures at $95 \%$ confidence level.

INAA does not require sample digestion and is recognized as the reference method. ${ }^{22}$ It was also used for comparison with the results showed in Table 4. As it can be seen, the amount of arsenic in the commercial fertilizer was similar for the three evaluated procedures, indicating that the proposed sample preparation procedures can release the arsenic from the sample to the solution. 
Table 4. Arsenic determination in mineral fertilizer and certified reference material (NIST SRM 695) by continuous flow hydride generation atomic absorption spectrometry (CF-HG-AAS), inductively coupled plasma optical emission spectrometer (ICP OES) and instrumental neutron activation analysis (INAA), employing the evaluated sample preparation procedures

\begin{tabular}{|c|c|c|c|c|c|}
\hline \multirow[b]{2}{*}{ Sample } & \multicolumn{2}{|c|}{ CF-HG-AAS } & \multicolumn{2}{|c|}{ ICP OES } & \multirow{2}{*}{$\begin{array}{c}\text { INAA } \\
\text { No digested }\end{array}$} \\
\hline & $\begin{array}{c}\text { Digester } \\
\text { block }\end{array}$ & $\begin{array}{c}\text { Microwave-assisted } \\
\text { digestion }\end{array}$ & $\begin{array}{l}\text { Digester } \\
\text { block }\end{array}$ & $\begin{array}{c}\text { Microwave-assisted } \\
\text { digestion }\end{array}$ & \\
\hline Mineral fertilizer / $\left(\mathrm{mg} \mathrm{kg}^{-1}\right)$ & $8.9 \pm 0.2$ & $9.7 \pm 0.7$ & $10.2 \pm 0.5$ & $10.6 \pm 0.7$ & $10.3 \pm 0.7$ \\
\hline Determined value / $\left(\mathrm{mg} \mathrm{kg}^{-1}\right)$ & $190 \pm 16$ & $205 \pm 18$ & $170 \pm 5$ & $164 \pm 3$ & - \\
\hline Certified value $/\left(\mathrm{mg} \mathrm{kg}^{-1}\right)$ & \multicolumn{4}{|c|}{$200 \pm 5$} & - \\
\hline Recovery / \% & 95 & 103 & 85 & 82 & - \\
\hline
\end{tabular}

a Certified reference material (NIST SRM 695). Mean $(\mathrm{n}=3) \pm$ SD.

\section{Figures of merit and comparison of official and CF-HG-AAS} proposed method

The first-order regression equation, correlation coefficient, linear range, limit of detection, limit of quantification and repeatability of the proposed CF-HG-AAS method are presented in Table 5. The accuracy of the method was evaluated by comparing certified value of SRM $695\left(200 \pm 5 \mathrm{mg} \mathrm{kg}^{-1}\right)$ with determined value $\left(186 \pm 9 \mathrm{mg} \mathrm{kg}^{-1}\right)$. At $95 \%$ confidence level, no differences were found between the certified and determined values.

The arsenic amount present in the commercial fertilizer determined by the proposed method was compared with official method 3051 (US EPA), recognized by Normative Instruction No. 24, $2007^{23}$ (Table 6). The paired $t$-test was applied for evaluating the agreement between the results and, at $95 \%$ confidence level, the results are statistically different. This fact may be related to sample preparation. The 3051 method employed concentrated nitric acid and, to be fit in accordance with CF-HG-AAS intrumental technique, dilution 2.5 folder higher than those need for proposed method (with diluted acid) was necessary, increasing the probability of analytical errors, mainly when the analyte is present in lower amount in the sample. In this case, the determined arsenic amount for the 3051 (US EPA), Brazilian sample preparation recommended the procedure is approximately $40 \%$ lower than that obtained
Table 5. Performance parameters for determination of arsenic (As) in mineral fertilizers samples

\begin{tabular}{lc}
\hline Parameter & Arsenic \\
\hline First order regression equation & $\mathrm{y}=0.0133 \mathrm{x}+0.0146$ \\
Correlation coefficient & 0.9926 \\
Linear range $/\left(\mu \mathrm{g} \mathrm{L}^{-1}\right)$ & $1.0-40.0$ \\
Limit of detection ${ }^{\mathrm{a}} /\left(\mathrm{mg} \mathrm{kg}^{-1}\right)$ & 0.20 \\
Limit of quantification ${ }^{\mathrm{b}} /\left(\mathrm{mg} \mathrm{kg}^{-1}\right)$ & 0.67 \\
Repeatability $\left([\mathrm{As}]=1.0,7.0 \text { and } 10.0 \mu \mathrm{g} \mathrm{L}{ }^{-1}\right)^{\mathrm{c}}$ & $7.56,2.28$ and $1.54 \%$ \\
\hline${ }^{\mathrm{a}} 3 \sigma_{\text {blank }} /$ slope, $\left.\mathrm{n}=10\right) ;{ }^{\mathrm{b}} 10 \sigma_{\text {blank }} /$ slope, $\mathrm{n}=10 ;{ }^{\mathrm{c}}$ relative standard deviation, \\
$\mathrm{n}=10$.
\end{tabular}

by the proposed method. The values found for arsenic in this fertilizer is below of maximum concentration established by Normative Instruction No. 27, $2006^{24}\left(500 \mathrm{mg} \mathrm{kg}^{-1}\right)$.

\section{Conclusions}

The proposed method showed adequate sensitivity and accuracy for the arsenic determination in mineral fertilizers. Sample preparation procedure optimized in this work is one significant advantage, because of the use of diluted acids permits low reagent consumption and reduction in residues generation. Another advantage is the sample throughput, simplicity, cost and the ease in being implemented in routine analysis.

Table 6. Arsenic amount obtained from the method 3051, defined by the United States Environmental Protection Agency (EPA), and of the proposed method in mineral fertilizer

\begin{tabular}{|c|c|c|}
\hline & EPA 3051 & Proposed method \\
\hline Procedure & $\begin{array}{c}\mathrm{HNO}_{3} \text { concentrated } \\
\mathrm{m}=0.500 \mathrm{~g} \\
\text { microwave oven }(10 \text { samples per round })\end{array}$ & $\begin{array}{c}7 \mathrm{~mol} \mathrm{~L}^{-1} \mathrm{HNO}_{3}+30 \%(\mathrm{~m} / \mathrm{m}) \mathrm{H}_{2} \mathrm{O}_{2} \\
\mathrm{~m}=0.200 \mathrm{~g} \\
\text { digester block with PFA vessels (30 samples per round) }\end{array}$ \\
\hline Sample & \multicolumn{2}{|c|}{ Arsenic concentration ${ }^{\mathrm{a}} /\left(\mathrm{mg} \mathrm{kg}^{-1}\right)$} \\
\hline Mineral fertilizer & $5.19 \pm 0.57$ & $8.90 \pm 0.18$ \\
\hline
\end{tabular}

${ }^{\mathrm{a}}$ Mean $(\mathrm{n}=3) \pm$ SD. PFA: Perfluoroalkoxy. 


\section{Acknowledgments}

The authors are grateful to the Fundação de Amparo à Pesquisa do Estado de São Paulo (FAPESP 2013/26672-5 and 2015/14488-0) and Conselho Nacional de Desenvolvimento Científico e Tecnológico (CNPq) for research and fellowships support.

\section{References}

1. Nziguheba, G.; Smolders, E.; Sci. Total Environ. 2008, 390, 53.

2. Jiao, W.; Chen, W.; Chang, A. C.; Page, A. L.; Environ. Pollut. 2012, 168, 44.

3. Molina, M.; Aburto, F.; Calderón, R.; Cazanga, M.; Escudey, M.; Soil Sediment Contam. 2009, 18, 497.

4. Lima, A. F.; Richter, E. M.; Muñoz, R. A. A.; J. Braz. Chem. Soc. 2011, 8, 1519.

5. Hartley, T. N.; Macdonald, A. J.; McGrath, S. P.; Zhao, F.; Environ. Pollut. 2013, 180, 259.

6. Hughes, M. F.; Beck, B. D.; Chen, Y.; Lewis, A. S.; Thomas, D. J.; Toxicol. Sci. 2011, 123, 305.

7. Kane, P. F.; Hall Jr, W. L.; J. AOAC Int. 2006, 89, 1447.

8. Borges, A. R.; Becker, E. M.; Lequeux, C.; Vale, M. G. R.; Ferreira, S. L. C.; Welz, B.; Spectrochim. Acta, Part B 2011, $66,529$.

9. Nachman, K. E.; Mihalic, J. N.; Burke, T. A.; Geyh, A. S.; Chemosphere 2008, 71, 500.

10. Macedo, S. M.; de Jesus, R. M.; Garcia, K. S.; Hatje, V.; Queiroz, A. F. S.; Ferreira, S. L. C.; Talanta 2009, 80, 974.

11. Borges, A. R.; Becker, E. M.; François, L. L.; de Jesus, A.; Vale, M. G. R.; Welz, B.; Dessuy, M. B.; de Andrade, J. B.; Spectrochim. Acta, Part B 2014, 101, 213.

12. Galuszka, A.; Migaszewski, Z.; Namiesnik, J.; TrAC, Trends Anal. Chem. 2013, 50, 78.

13. Rocha, D. L.; Batista, A. D.; Rocha, F. R. P.; Donati, G. L.; Nóbrega, J. A.; TrAC, Trends Anal. Chem. 2013, 45, 79.
14. Souza, S. O.; da Costa, S. S. L.; Santos, D. M.; Pinto, J. S.; Garcia, C. A. B.; Alves, J. P. H.; Araujo, R. G. O.; Spectrochim. Acta, Part B 2014, 96, 1.

15. Takase, I.; Pereira, H. B.; Luna, A. S.; Grimberg, P.; de Campos, R. C.; Quim. Nova. 2002, 25, 1132.

16. Kumar, A. R.; Riyazuddin, P.; TrAC, Trends Anal. Chem. 2010, 29, 166.

17. Varejão, E. V. V.; Bellato, C. R.; de Mello, J. W. V.; Fontes, M. P. F.; R. Bras. Ci. Solo 2009, 33, 875.

18. Dedina, J.; Tsalev, D. L.; Hidride Generation Atomic Absorption Spectrometry; John Wiley \& Sons: Oxford, 1995.

19. Batista, E. F.; Pessoa, A. G. G.; Guerra, M. B. B.; Miranda, K.; Pereira Filho, E. R.; Food Anal. Methods 2013, 6, 1212.

20. Batista, E. F.; Augusto, A. S.; Pereira Filho, E. R.; Anal. Methods 2015, 7, 329.

21. Guerra, M. B. B.; Carapelli, R.; Miranda, K.; Nogueira, A. R. A.; Pereira Filho, E. R.; Anal. Methods 2011, 3, 599.

22. Krachler, M.; Emons, H.; Barbante, C.; Cozzi, G.; Cescon, P.; Shotyk, W.; Anal. Chim. Acta. 2002, 458, 387.

23. Ministério da Agricultura (Brasil); Instrução Normativa No. 24, de 20 de junho de 2007; Reconhece Métodos Analíticos Constantes do Anexo da IN, para a Determinação de Metais Pesados Tóxicos em Fertilizantes, Corretivos Agrícolas, Condicionadores de Solo e Substratos para Plantas; Diário Oficial da União de 21 de junho de 2007, Seção 1, Brasília, DF.

24. Ministério da Agricultura (Brasil); Instrução Normativa No. 27, de 05 de junho de 2006; Dispõe Sobre os Limites Estabelecidos para Agentes Fitotóxicos, Patogênicos ao Homem, Animais e Plantas, Metais Pesados Tóxicos, Pragas e Ervas Daninhas, Presentes em Fertilizantes, Corretivos, Inoculantes e Biofertilizantes; Diário Oficial da União de 09 de junho de 2006, Seção 2, Brasília, DF.

Submitted: October 20, 2015

Published online: January 27, 2016

FAPESP has sponsored the publication of this article. 